\title{
An Evaluation of Financial Stress for Islamic Banks in Indonesia Using a Bankometer Model
}

\author{
Teguh Budiman ${ }^{1 *}$, Aldrin Herwany ${ }^{2}$ and Farida Titik Kristanti ${ }^{3}$ \\ ${ }^{1,2}$ Department of Management \& Business,, Faculty of Economics \& Business, Universitas Padjadjaran, Indonesia. \\ ${ }^{3}$ Department of Accounting, Faculty of Economics \& Business, Telkom University, Bandung, Indonesia.
}

\begin{abstract}
Objective - In recent years, the market share of Indonesian Islamic banks has declined. The purpose of this study is to assess the financial distress being experienced by Islamic banks in Indonesia by using the Bankometer's score. This study will also uncover any differences between listed and non-listed Islamic banks using the Bankometer model. The Bankometer model is a model developed by the IMF (2000) to measure the financial soundness of banks.

Methodology/Technique - The study uses data obtained between 2011 and 2015 using a purposive sampling model. The sample consists of 11 Islamic Banks in Indonesia.

Findings - The results show that all Islamic banks are categorized as very healthy throughout the period of the research. Using and independent t-test, it is shown that there are differences between non-performing loans from listed and nonlisted Islamic banks. However, there are no significant differences between Variable Capital Asset, Equity Asset, Cost to Income and Loan to Asset.
\end{abstract}

Novelty - The study uses Bankometer's score to evaluate financial distress.

Type of Paper: Empirical

Keywords: Bankometer Model; Financial Distress; Islamic Banks.

JEL Classification: E44, F14, G01.

\section{Introduction}

The banking industry is an intermediating institution that should be able to prove that their business model is sustainable and able to contribute to economic growth and national stability. Brown (2003) and Safiullah (2010) explain the role of the banking industry in the economy to reach national sustainability of economic development. Failure of the banking industry will not only threaten national economic growth, but also the international financial scheme as well as international economic development (Jan \& Marimuthu, 2015).

Due to the effect of banking activity on the world economy, regular supervision of the banking industries compliance with industry obligations is required (Rashid \& Nishat, 2009). Banks play a central role in the national economy and should therefore always perform at optimal levels. However, despite the banking

\footnotetext{
* Paper Info: Received: December 8, 2016

Accepted: June 28, 2017

* Corresponding author:

E-mail: teguh.unpad2014@gmail.com

Affiliation: Faculty of Economics \& Business, Universitas Padjadjaran, Indonesia.
} 
industry adopting various sustainability measuremes, whether internal or external, it seems that they often encournter financial problems (financial distress) and deterioration of the performance of the banking industry is still occuring. Literature in this area shows that Islamic banks have increased stability when compared to conventional banks, however they are still not immune to the toils of financial distress. For instance, Husna and Rahman (2012) explain that subprime crisis has affected the liquidity of a major bank in Dubai. Another example includes the financial crisis between 1998 and 1999 which affected the Islamic bank. Magd and McCoy (2014) state that the Islamic Financial Industry is not fully immune from the world's economic condition. It is therefore necessary for the Islamic bank to conduct a thorough examination of their current financial condition in order to minimise the prevalence of financial distress.

There are various methods for measuring the health of a bank. The Bankometer model is recommended by the IMF (2000) and is frequently used by many researchers. This model has a simple procedure with minimum parameter, but results in maximum accuracy (Kattel, 2014). Another commonly used method is the Risk Based Bank Rating (RBRR). This model works by measuring the Risk Profile, Good Corporate Governance and Earning, Capital (RGEC) of a bank, based on the Central Bank of Indonesia Regulation no.13/1/PBI/2011, which replaced the previous method, CAMELS. Erari, Salim, Idrus and Djumahir (2013) make an analysis of bank performance using the Cael, Z-Score and Bankometer methods. The result show that the Cael and Bankometer methods generate the same results. This study also states that the S-Score method is not appropriate for application to the Indonesian Banking Industry. Many studies have used the Bankometer model to measure a bank's financial conditions. Rahman (2007) applied the Bankometer model using data from commercial banks in Bangladesh for the period between 2010 and 2015. That study shows that the Bankometer model may assist management teams in making decisions during insolvency periods and to reveal inefficiencies in their operations.

Yamen and Ali (2016) conducted a study based in Jordan, measuring their bank's financial conditions by applying the Bankometer model. The result show that commercial banks in Jordan have strong financial conditions. In Pakistan, Ashraf and Tariq (2016) also conducted a study using the Bankometer model and ZScore from Altman, to measure their bank's financial conditions for the period between 2006 and 2014. That study found that each model yeilded different results. In India, Shamanth and Rajgopal (2016) state that the Bankometer model could be used as an early warning system in scoring a bank's financial performance. Katell (2014) states that both private banks and joint venture banks are have financial conditions but private banks are in a better position when compared to joint venture banks. Katell (2014) states that the Bankometer model helps bank management teams to mitigate the risks of insolvency, with control and proper supervision.

Data from the World Bank Islamic Competitiveness Report (2016) shows a decrease in Indonesian Islamic Bank market shares from 2011 to 2014. In 2011, Indonesia's Islamic Bank had a market share of 0.6\% which decreased to $0.3 \%$ in 2012 . This decrease continued in 2014 , dropping to $0.1 \%$. By understanding the condition of Islamic banks in Indonesia, it is possible to design a precautionary plan to avoid bankruptcy.

There are several non-internal factors that contribute to the occurrence of financial distress of a company such as interest rates, negative industry performance, and increased competition (Altman and Hotchkiss, 2005). The present study is significant because Islamic Banks are one of the main pillars supporting the national economy. Aspal and Malhorta (2013) state that the health of the Islamic bank is important not only for depositors but also for shareholders and the entire economy.

This study will discuss the different ratios that are used in the Bankometer model, between listed and nonlisted Islamic banks. The capital market is one of the places where a company may raise their capital before they are listed. Budiman, Kristanti and Wardhana (2017) believe that one way to improve the performance of Islamic banks is by raising capital through the sale of shares on the stock market. By using a different test for listed and-non listed banks, it is possible to determine whether listed banks have better financial performance as compared to non-listed banks. The results of this test are useful for both banks and the government. 


\section{Literature Review}

Financial distress can effect a company's financial situation, working capital, ability to pay and sales growth. Altman and Hotchkiss (2005) define distress with economic criteria, i.e. realisation of return on investment capital (which takes into account risks) is significantly and continuously lower than similar investment returns. Failure in accordance with financial criteria can be defined as the insufficiency of cash flow to meet ongoing obligations. These liabilities include liabilities to suppliers and employees, including the costs of legal processes as well as the failure to repay any principal and interest on loans (Wruck, 1990). Whitaker (1999) states that the distress of a company in its' first-year of operation is higher because their cash flow is smaller when compared to the long-term debt of the company. Beaver (1966) states that financial distress is a large shortage of income (in corporate finance), which causes the failure of payments on preferred stock dividends and corporate bonds, often leading to bankruptcy. Altman (1968) and Ohlson (1980) define distress as the act of going into bankruptcy.

Altman's Z-Score is used by Laila and Widihadnanto (2017) to predict financial distress. Other studies include Arulvel and Balaputhiran (2013) in Sri Lanka, Hanif, Tariq, Tahir and Momeneen (2012) in Pakistan, Fayed (2013) in Egypt. These studies all found that the Bankometer model (S-Score) is more appropriate than the Altman Z-Score model.

The S-Score Formula can be used to predict distress levels of banks using a multivariate formula applied. IMF (2000) recommends six different financial ratios which could be combined to measure the difference between a bank experiencing financial distress and a bank in a strong financial position. Discriminant functions recommended by the IMF include:

$$
S=1.5 C A+1.2 E A+3.5 C A R+0.6 N P L+0.3 C I+0.4 L A
$$

Where:

$\begin{array}{ll}\text { CA } & =\text { Capital to Asset Ratio }(\geq 4 \%) \\ \text { EA } & =\text { Equity to Asset Ratio }(\geq 2 \%) \\ \text { CAR } & =\text { Capital Adequacy Ratio }(\geq 8 \%) \\ \text { NPL } & =\text { Non Performing Loan Ratio }(\leq 5 \%) \\ \text { CI } & =\text { Cost to Income Ratio }(\leq 40 \%) \\ \text { LA } & =\text { Loan to Asset Ratio }(\leq 65 \%)\end{array}$

With Criteria Score:

- S-Score $>70$ are classified as banks with healthy financial conditions with no financial difficulties.

- S-Score $<70$ are in the grey area and are classified as banks with financial problems. These banks have an equal probability of bankrupt and their survival depends heavily on the decisions of management.

- S-Score $<50$ are classified as banks with heavy financial problems and a high risk of bankruptcy.

Signaling theory places importance on the information issued by a company for external investment.

It is important for management to report and disclose the circumstances of their financial stability to external investors (Healy and Palepu, 2001). According to Bini et al. (2011), a bank with higher profitability is likely to provide complete and better information to the market. Accounting practices act as a signal that a company has a positive future outlook in which an investor may be interested. Therefore, if a company wants their shares to be purchased by investors, the company must disclose their financial reports transparently. This research focuses on the Bankometer model and the hypothesess for this study are:

- $\mathrm{H}_{1}$ : There is a difference between the Capital to Asset Ratio of listed and non-listed banks.

- $\mathrm{H}_{2}$ : There is a difference between the Equity to Asset Ratio of listed and non-listed banks. 
- $\mathrm{H}_{3}$ : There is a difference between the Non-Performing Loan Ratio of listed and non-listed banks.

- $\mathrm{H}_{4}$ : There is a difference between the Cost to Income Ratio of listed and non-listed banks.

- $\mathrm{H}_{5}$ : There is a difference between the Loan to Asset Ratio of listed and non-listed banks.

\section{Methodology}

This study uses secondary data from the financial reports collected from the websites of each Islamic Bank in Indonesia for the period between 2011 and 2015. Descriptive analysis is used to elaborate on the measurement results. 11 Islamic Banks were selected for research sample using purposive random sampling with the following criteria: they must have published complete data for the period between 2011 and 2015 . Accordingly, BTPN Syariah bank was excluded as it was only established in 2014.

The Bankometer model was used to explore the banks' financial condition. The measurement obtained from the S-Score was then compared with the criteria used in this model.

To test the hypothesis in this study, an independent t-test was used. This test compares the differences between two values which provide an average standard error and standard error from the sample. The first step involves testing whether there are any difference between both of the variance in population. Then, the t-test was run to determine the average value of the difference significantly.

\section{Results}

The results form the S-Score measurement (by using the Bakometer model) displayed in Table 1 show that all Indonesian Islamic Banks are in very good financial positions because they have a S-Score of more than $70 \%$. This means that all Indonesian Islamic banks were not experiencing financial distress during the 2011 to 2015 period. The lowest value was experienced by BJBS in $2013(84.7 \%)$ while the highest value was acquired by MYS $(220.1 \%)$.

Table 1. Bankometer Model Results (S-Score) for 2011-2015

\begin{tabular}{|l|r|r|r|r|r|r|r|r|r|r|r|}
\hline & \multicolumn{1}{|c|}{ MUA } & \multicolumn{1}{l|}{ VIS } & \multicolumn{1}{l|}{ BRIS } & \multicolumn{1}{c|}{ BJBS } & \multicolumn{1}{l}{ BNIS } & \multicolumn{1}{l}{ BMRS } & \multicolumn{1}{l}{ BMS } & \multicolumn{1}{l}{ BPS } & \multicolumn{1}{l}{ BSK } & \multicolumn{1}{l}{ BCS } & MYS \\
\hline 2011 & 112.5 & 116.8 & 208.1 & 92.1 & 109.1 & 131.1 & 146.3 & 111.3 & 136.9 & 140.8 & 134.8 \\
\hline 2012 & 111.4 & 127.9 & 152.8 & 100.6 & 112.1 & 135.2 & 131.5 & 95.7 & 138.8 & 142.8 & 140.3 \\
\hline 2013 & 137.5 & 114.7 & 160.3 & 84.7 & 141.2 & 128.7 & 139.0 & 97.3 & 146.2 & 136.8 & 133.1 \\
\hline 2014 & 148.5 & 172.6 & 151.7 & 120.0 & 157.9 & 135.5 & 138.7 & 92.3 & 146.5 & 145.2 & 154.2 \\
\hline 2015 & 150.0 & 147.6 & 123.1 & 98.0 & 151.3 & 142.3 & 150.5 & 131.2 & 144.1 & 144.5 & 220.1 \\
\hline Average & 131.98 & 135.92 & 159.2 & 99.08 & 134.32 & 134.56 & 141.2 & 105.56 & 142.5 & 142.02 & 156.6 \\
\hline
\end{tabular}

Source: Data Bank Financial Report, proceeded

In addition, the results of the different test with the independet t-test show that only NPL has a significant difference between listed and non-listed Islamic banks, because the probability is $<0.05$. Other variables (CA, EA, CAR, CI and LA) do not show any difference between listed and non-listed banks (Table 2). 
Table 2. Satistical Results

\begin{tabular}{|c|c|c|c|c|c|}
\hline Variable & F-test & Sig. & $\begin{array}{c}\text { Equal variance assumed/ Equal } \\
\text { variance not assumed }\end{array}$ & t & $\begin{array}{c}\text { Sig.(2- } \\
\text { tailed) }\end{array}$ \\
\hline CA & 0.200 & 0.887 & Equal variance assumed & 1.093 & 0.279 \\
\hline EA & 0.101 & 0.752 & Equal variance assumed & 1.626 & 0.110 \\
\hline CAR & 0.071 & 0.790 & Equal variance assumed & 1.434 & 0.158 \\
\hline NPL & 4.662 & 0.035 & Equal variance not assumed & -3.036 & 0.016 \\
\hline CI & 0.000 & 0.990 & Equal variance assumed & -1.765 & 0.083 \\
\hline LA & 1.304 & 0.259 & Equal variance assumed & -1.094 & 0.279 \\
\hline
\end{tabular}

Source: Estimation Results

The statistical tests show that the results of the probability of F-Lavene test is simply that the NPL factors need to use Equal Variance not assumed, because it has the probability of 0.035 , which is smaller than 0.05 . Meanwhile, other factors such as CA, EA, CAR, CI and LA use equal variance assumed, because it has a probability greater than 0.05 .

\section{Discussion}

The result of the Bankometer model shows that no Islamic banks in Indonesia are experiencing financial distress. This can be seen from the value of the S-score which is greater than $70 \%$, suggesting that all Islamic banks in Indonesia had a stronge financial position during the period of research. When calculated over five years, the highest score belongs to BRI Syariah while the smallest score belongs to BJBS.

When using a differential test for listed and non-listed banks, only NPL shows a significant difference. Listed banks have smaller NPL (1.18\%) compared to non-listed banks (2.41\%). This shows that listed Islamic banks are able to manage their financial situation better than non-listed Islamic banks. These results are in line with Budiman et.al. (2017) conducted in Indonesia, using RGEC (Risk, Governance, Earning and Capital) as the independent variable. That study found that NPF and BOPO have significant differences in listed Islamic banks as compared to non-listed banks.

Despite no indication of a significant difference between listed and non-listed banks, the average value of listed Islamic banks is higher than non-listed Islamic banks. Capital to Asset Ratio is used to measure the size of an asset that could be financed from the equity or other long term debt of the bank. A higher ratio level means better bank performance, as those assets are financed by long term debt. The statistical results show that the CA of listed Islamic banks is larger than non-listed Islamic banks.

Equity to Asset ratio is one of the main financial ratios used to evaluate the financial condition of a bank and their long term profitability. A higher level of this ratio means that the bank is categorized as further away from bankruptcy conditions. The statistical test shows that listed Islamic banks have better average value in this field.

The Capital Adequacy Ratio of listed Islamic banks is bigger than non-listed Islamic Banks. CAR is an used when valuating the capital aspects of abank. There is a component of capital in the measurement. Higher capital levels will increase the ratio of CAR, which means that the bank has enough capital to cover ongoing expenses relating to their business operations. Any increase in capital will decrease the cost of their services provided, thus allowing them to use their own capital and increase their profitability.

Cost to Income is used to measure the bank's ability to manage their own business operations. The statistical results show that listed Islamic banks have a lower value than non-listed Islamic banks. This means that listed Islamic banks are more efficient than non-listed Islamic banks in term of cost management. A lower ratio of BOPO means better bank management performance, as a result of more efficient allocation of company resources. 
Loan to Asset Ratio, also called Assets to Loan Ratio, is the ratio used to measure the amount of credit distribution compared to the bank's total assets. A higher Loan to Asset ratio causes lower bank liquidity levels. Listed Islamic banks have lower Loan to Asset ratio's than non-listed Islamic banks. This means they distribute credit more than non-listed Islamic banks. Since listed Islamic banks are more efficient in term of cost management, they perform better when compared to non-listed Islamic banks.

\section{Conclusion}

All Indonesia Islamic banks studied during the research period demonstrated positive financial conditions. The results of the difference tests show that only NPL has a significant difference between listed and nonlisted Islamic banks. These results show that listed Islamic banks are more capable of managing their credit than non-listed Islamic banks. As a result, listed Islamic banks are more likely to be more appealing to investors as a result of their favourable financial performance. Despite the other variables show no significant difference between listed and non-listed banks, it is concluded that Islamic banks perform better than nonlisted Islamic banks. Therefore, an unlisted bank may consider listing their company, in order to immediately improve its performance. The government as a regulator is advised to encourage Islamic banks that are currently unlisted to consider listing on the Indonesian Stock Exchange.

This study only uses one model to evaluate the financial condition of Indonesia Islamic Bank. Therefore, future research could apply different financial conditions to the measurement model. Future studies could also consider a comparison between conventional banks and Islamic banks.

\section{References}

Altman. E.I. (1968). Financial Ratios, discriminant analysis and the prediction of corporate bankruptcy. Journal of Finance, 23(4), 589-609

Altman, E.I., and Hotchkiss, E. (2005). Corporate Financial Distress and Bankruptcy: Predict and Avoid Bankruptcy, Analyze and Invest in Distress Debt, 3th Edition, New Jersey, John Wiley \& Sons.

Arulvel, K. K., \& Balaputhiran, S. (2013). Financial position of banking sector: A comparative study between state and private sector banks in Sri Lanka. ACADEMICIA: An International Multidisciplinary Research Journal, 3(2), 212221.

Ashraf, A., \& Tariq, Y. B. (2016). Evaluating the Financial Soundness of Banks: An Application of Bankometer on Pakistani Listed Banks. IUP Journal of Financial Risk Management, 13(3), 47-63.

Aspal, P. K., \& Malhotra, N. (2013). Performance Apprisal of Indian Public Sector Banks. World Journal of Social Science, 3, 71-88.

Beaver. W.H. (1996). Financial Ratio as Predictor of Failure, Empirical Research in accounting: Selected Studies. Journal of Accounting Research, 5, 71-111.

Bini, L. et.al. (2011). Signalling Theory and Voluntary Disclosure to Financial Market (evidence from the profitability indicators published in the annual report). Paper presented at the 34th EAA Annual Congress, 20-22 April 2011.

Brown, K. (2003). Islamic banking comparative analysis. The Arab Bank Review, 5(2). pp. 43-50.

Budiman,Teguh., Farida Titik Kristanti, \& Wardhana. (2017). Islamic Bank Listed in Financial Market: Risk, Governance, Earning, and capital. Journal of Islamic Economics, 9(1), 1-12.

Erari, A., Salim, U., Idrus, M., \& Djumhir. (2013). Financial Performance Analysis of PT. bank Papua: Application of Cael, Z - Score and Bankometer. Journal of Business and M anagement, 7(5), 08-16.

Fayed, M. E. (2013). Comparative performance study of conventional and Islamic banking in Egypt. Journal of Applied Finance and Banking, 3(2), 1-14

Hanif, D., Tariq, M., Tahir, A., \& Momeneen, W. U. (2012). Comparative performance study of conventional and Islamic banking in Pakistan. International Research Journal of Finance \& Economics, 83, 61-73.

Healy, P.M. \& K.G. Palepu. (2001). Information asymmetry, corporate disclosure, and the capital markets: A review of the empirical disclosure literature. Journal of Accounting and Economics, 31, 405-440.

Husna, H. Hurul \& R. Abdul Rahman. (2012). Financial Distress - Detection Model for Islamic Banks. International Journal of Trade, Economics and Finance. 3(3), 158-163.

IMF. (2000). Macro prudential Indicators of Financial System Soundness. International Monetory Fund. 
Jan, A \& Marimuthu, M. (2015). Bankruptcy and Sustainability: A Conceptual Review on Islamic Banking Industry. International Journal of Economics and Financial Issues. 6(1), 332-346.

Kattel, I.K. (2014). Evaluating the Financial Solvency of Selected Comercial Banks of Nepal: An application of Bankometer. Journal of Advanced Academic Research (JARR), 1(1) 88-95.

Laila, N. \& Widihadnanto, F. (2017). Financial distress prediction using bankometer model on Islamic and Konvesional Banks: evidence from Indonesia. International Journal of Economics and Management, 11(SI), 169-181.

Magd, H. A., \& McCoy, M. P. (2014). Islamic Finance Development in the Sultanate of Oman: Barriers and Recommendations. Procedia Economics and Finance, 15, 1619- 1631.

Ohlson, H. (1980). Financial ratios and the probabilistic prediction of bankruptcy. Journal of Accounting Research, 18(1), $109-113$

Rahman, M.Z (2007). Financial Soundness Evaluation of Selected Commercial Banks in Bangladesh: An Application of Bankometer Model. Journal of Advanced Academic Research (JARR), 8(2), 63-70.

Rashid, M. \& Nishat, A. (2009). Disparity of Performance Indicators of Islamic Banks: Study on Bangladesh. International Journal of Business and Management, 4(8).

Safiullah, M. (2010). Superiority of conventional banks \& Islamic banks of Bangladesh: A comparative study. International Journal of Economics and Finance, 2(3), 109-207.

Shamanth, N \& Rajgopal, M. (2016). Assessment of Financial Health of Select Private Sector and Foreign Banks in India: An Application of Bankometer Model. International Journal of Engineering and Management Research, 6(4), 2630.

Whitaker, R.B. (1999). The Early Stages of Finbancial Distress. Journal of Economics and Finance, 23(2), 123-133.

World Islamic Bank Islamic Competitiveness Report. (2016)

Wruck, K. H. (1990). Financial Distress, Reorganization and Organizational Efficiency, Journal of Financial Economics, 27, 419-444

Yamen, I.Y \& Ali, M.S. (2016). Evaluating the Financial Soundness of the Jordanian Commercial Banks by Applying BankoMeter's Model. Research Journal of Finance and Accounting, 7(2), 124-130. 